SOUTHERN BRAZILIAN, JOURNAL OF CHEMISTRY

SOUTH. BRAZ, J. CHEM., Vol. 21, No. 21, 2013

\title{
TESTING OF A DEFLUORIDATING FILTER USING MgO-CaO-CaCl 2 FOR USE IN RURAL RAJASTHAN
}

\author{
K. Margandan ${ }^{x}$, R. Agrawal ${ }^{1}$, K.Singh ${ }^{1}$, R. Acharya $^{2}$, S. Sharma ${ }^{1}$, K Qanungo ${ }^{1}$
}

\author{
kushalq@rediffmail.com \\ ${ }^{1}$ Department of Applied Science \& Humanities, \\ Faculty of Engineering \& Technology, \\ Mody Institute of Science \& Technology (Deemed University), \\ Lakshmangarh-332311, Dist. Sikar, Rajasthan, INDIA \\ ${ }^{2}$ Dept. of Science and Technology, Govt. of Rajasthan, \\ $506,4^{\text {th }}$ Floor Mini Secretariat \\ Bani-Park, Jaipur, Rajasthan, INDIA
}

\begin{abstract}
A Magnesium Oxide based defluoridation technique using $\mathrm{MgO}-\mathrm{CaO}$-Calcium Chloride and pH adjustment by Sodium Bisulphate has been suitably modified for use with fluoride contaminated local groundwater having high alkalinity. Taking into consideration the high bicarbonate concentration in raw ground water the proportion of the lime has been changed. It was found that sodium bisulphate was not suitable for pH adjustment due to high concentration of sulphate in the pH adjusted water. Therefore dilute $\mathrm{HCl}$ was used instead. Six trials of the adapted defluoridation technique have been carried out in the laboratory successfully at 50 liter scale.
\end{abstract}

KEY WORDS: Defluoridation, Defluoridating Filter, $\mathrm{MgO}, \mathrm{CaO}$, Calcium Chloride

\section{RESUMO}

Uma técnica de defluoretação usando $\mathrm{MgO}-\mathrm{CaO}$-Cloreto de Cálcio e ajuste de $\mathrm{pH}$ com bisulfato de sódio foi modificada com éxito para água contaminada com fluoreto e com alcalinidade elevada. Considerando a alta concentração de bicarbonato na água natural, a proporção de CaO foi modificada, $O$ bisulfato de sódio não foi adequado para ajuste do $p H$ devido à alta concentração resultante de sulfato. Consequentemente, $\mathrm{HCl}$ diluido foi usado. Os resultdos experimentais com amostras de 50 litros de água foram satisfatórios para remover o fluoreto.

PALAVRAS CHAVE: Defluoretação, Filtro para Remoção de Fluoreto, Mgo, CaO, Cloreto de Cálcio

VISTT OUR SITE: http://www.sbjchem.he.com.br 


\section{SOUTHERN BRAZILIAN JOURNAL OF CHEMISTRY \\ SOUTH. BRAZ. J. CHEM., Vol. 21, No. 21, 2013}

80

Defluoridating Filter

\section{INTRODUCTION}

The desert state of Rajasthan in India primarily depends upon groundwater for meeting its drinking water requirements. The groundwater in Rajasthan ${ }^{1}$ has fluoride in excess of the permissible limit set by WHO of $1.5 \mathrm{ppm}^{2}$. Flouride is known to be beneficial if present in the desirable concentration of 1 ppm and has adverse impacts on human health if present in excess ${ }^{34}$

Magnesium Oxide is known to remove fluoride from water since 1940 's $\mathrm{s}^{5}$. Since then various researchers have studied this process ${ }^{6} 7891011 . \mathrm{MgO}$ being non-toxic, relatively easily available and cheap is a suitable adsorbent for $\mathrm{F}^{-}$removal.

A new method of defluoridation based on $\mathrm{MgO}-\mathrm{CaO}-\mathrm{CaCl}_{2}$ and $\mathrm{pH}$ adjustment using $\mathrm{NaHSO}_{4}$ has recently been reported from the Indian Institute of Science, Bangalore, India ${ }^{12} 1314$. The ratio of various chemicals used depends on fluoride concentration and bicarbonate concentration in the raw water. The ground water in Rajasthan has very high concentration of bicarbonates. A project supported by the Water Technology Initiative of the Department of Science and Technology, Govt. of India, New Delhi involves the testing and field trials of this filter in the fluoride affected Lakshmangarh Tehsil (subdivision), in the Sikar District of Rajasthan. Due to higher alkalinity of the local fluoride contaminated ground water, the defluoridation technique had to suitably be modified, and in this paper we report the preliminary findings of our study.

\section{MATERIALS AND METHODS}

\section{Fabrication and Testing of the Filter}

Food grade drums (50 liters capacity) were purchased from Time Technoplast (New Delhi). Plastic taps were fixed $2.5 \mathrm{~cm}$ above the base of the containers Fig. 1. Calcium oxide (Mahalaxmi Traders, Ajmer) was purchased locally from Laxmangarh in $5 \mathrm{~kg}$ plastic sacks. 
SOUTHERN BRAZILIAN, JOURNAL OF CHEMISTRY SOUTH. BRAZ. J. CHEM. , Vol. 21, No. 21, 2013

K.Margandan, R.Agrawal, K.Singh, R.Acharya, S. Sharma and K. Qanungo

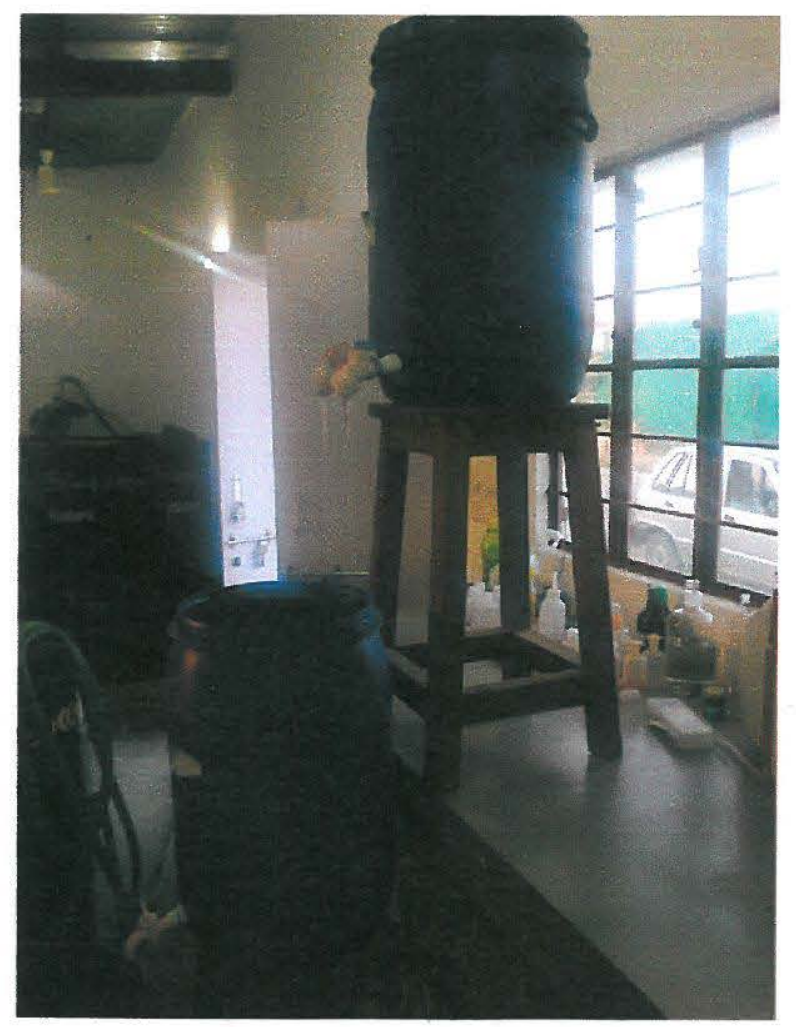

Fig. 1 Photograph of Testing of the Fluoride Filter in Laboratory.

VISIT OUR SITE: http://www.sbjchem.he.com.br 


\title{
SOUTHERN BRAZILIAN JOURNAL OF CHEMISTRY
}

SOUTH. BRAZ. J. CHEM., Vol. 21, No. 21, 2013

82

\author{
Deftworidating Fitter
}

Technical grade magnesium oxide, (light) was purchased from R/S Enteprises, Jaipur. Calcium Chloride Dihydrate (AR), conc. $\mathrm{HCl}$ (AR) was purchased from $\mathrm{CDH}$ (India) and Rankem (India), respectively.

Fluoride contaminated ground water was brought from village Shola $30 \mathrm{~km}$ away from the Institute in mini water tankers and transferred to 500 liter drums in the laboratory.

Fixed volumes of $7.5 \% \mathrm{CaCl}_{2}$ solution in demineralised water was added to 50 liters fluoride contaminated water and stirred using plastic PVC pipes. Weighed amounts of $\mathrm{MgO}$ and $\mathrm{CaO}$ were added to it, and the water stirred vigorously using a PVC plastic pipe. The water was left overnight undisturbed. $\mathrm{MgO}$ and $\mathrm{Ca}(\mathrm{OH})_{2}$ flocks settled down to the bottom of the container in form of white sludge. The supernatant water was filtered through six layers of cotton cloth tied to the mouth of the tap into another food grade container fitted with plastic tap Fig. 1 . Hydrochloric acid $(0.38 \mathrm{~N})$ in demineralised water was added with constant stirring to the filtered water till the $\mathrm{pH}$ of the treated water was in between 6.5 to 8.5 , and fit for the human consumption.

\section{Water Testing}

Fluoride was measured by using a Fluoride Ion Selective Electrode (Orion Thermo Scientific) using TISAB Buffer. Total Hardness, Calcium Hardness was determined by EDTA method. Carbonate and Bicarbonate was determined by titrating with $\mathrm{H}_{2} \mathrm{SO}_{4}$. For chloride, titration with silver nitrate was used. Duly calibrated $\mathrm{pH}$, TDS meter was used for determining pH and TDS. Sodium and Potassium was determined by Flame Photometer (ESICO). Nitrate was measured by measuring the absorbance at $220 \mathrm{~nm}$ and $270 \mathrm{~nm}$. Sulfate was determined by turbidity method using a colorimeter.

\section{RESULTS AND DISCUSSION}

$\mathrm{MgO}$ hydrates in water to form $\mathrm{Mg}(\mathrm{OH})_{2}{ }^{613}$

$$
\mathrm{MgO}+\mathrm{H}_{2} \mathrm{O} \rightarrow \mathrm{Mg}(\mathrm{OH})_{2}
$$




\section{SOUTHERN BRAZILIAN JOURNAL OF CHEMISTRY \\ SOUTH. BRAZ. J. CHEM., Vol. 21, No. 21, 2013}

K.Margandan, R.Agrawal, K.Singh, R.Acharya, S. Sharma and K. Qanungo

Since the ionic radii of fluoride and hydroxide are similar, $\mathrm{OH}^{-}$ions in the crystal lattice $\mathrm{Mg}(\mathrm{OH})_{2}$ gets substituted by $\mathrm{F}^{-1511} 12$.

$$
\mathrm{Mg}(\mathrm{OH})_{2}+\mathrm{F}^{n} \rightarrow \mathrm{Mg}(\mathrm{OH})_{2-\mathrm{y}} \mathrm{F}_{\mathrm{y}}
$$

For defluoridation using $\mathrm{MgO}-\mathrm{CaO}-\mathrm{CaCl}_{2}-\mathrm{NaHSO}_{4}{ }^{12}{ }^{13}$, the concentration of bicarbonate in raw water is the critical parameter. A preliminary sampling of the ground water of village Shola, a fluorosis affected village in Lakshmangarh indicated a very high $\mathrm{HCO}_{3}{ }^{-}$concentration of $937 \mathrm{ppm}$ and high fluoride concentration of $2.15 \mathrm{ppm}$ (Table 1). The ratio derived for $\mathrm{MgO}$ $\mathrm{CaO}-\mathrm{CaCl}_{2}$ treatment method as given in the application notes ${ }^{16}$ are only up to $700 \mathrm{ppm} \mathrm{HCO}_{3}{ }^{2-}$ concentration. Since the bicarbonate concentration in raw water sample was very high, we increased the lime dosage from the maximum dosage of $0.5 \mathrm{gm}$ to $0.75 \mathrm{gm}$ (Table 1). This is to ensure the presence of enough $\mathrm{Ca}^{2+}$ ions in the solution, as in the basic medium $\mathrm{Ca}^{+2}$ ions react with $\mathrm{HCO}_{3}{ }^{-}$ions to form $\mathrm{CaCO}_{3}$ as precipitate

$$
\mathrm{HCO}_{3}{ }^{-1}+\mathrm{Ca}^{2+}+\mathrm{OH}^{-1} \rightarrow \mathrm{CaCO}_{3} \downarrow+\mathrm{H}_{2} \mathrm{O}
$$

The concentration of bicarbonate ions has to be low in the raw water to be treated by this process, otherwise it will get converted to carbonate ions when a mixture of $\mathrm{MgO}-\mathrm{CaO}-\mathrm{CaCl}_{2}$ is added and the $\mathrm{pH}$ of water become basic

$$
\mathrm{HCO}_{3}^{-}+\mathrm{OH}^{-1} \rightarrow \mathrm{CO}_{3}^{-}+\mathrm{H}_{2} \mathrm{O}
$$

Moreover in the $\mathrm{pH}$ adjustment step by $5 \% \mathrm{NaHSO}_{4}$ solution, one equivalent more of $\mathrm{NaHSO}_{4}$ would be consumed by the $\mathrm{CO}_{3}{ }^{2-}$ ions that are generated above.

$$
\mathrm{CO}_{3}{ }^{2-}+\mathrm{HSO}_{4}^{-1} \rightarrow \mathrm{HCO}_{3}^{-}+\mathrm{SO}_{4}{ }^{2-}
$$

The $\mathrm{MgO}$ dosage was kept at minimum (1.0 gm/lit) since the $\mathrm{F}^{\prime \prime}$ concentration in the raw water as not very high $\left(\mathrm{MgO}\right.$ dosage $1.0 \rightarrow 1.5$ for $\mathrm{F}^{-}$concentration 1.5 to $7 \mathrm{ppm}$ ).

In a preliminary experiment, 1.0 liter sample was treated with $1.0 \mathrm{gm} \mathrm{MgO}, 0.75 \mathrm{gm} \mathrm{CaO}$, $4.0 \mathrm{ml}$ of $7.5 \%$ of $\mathrm{CaCl}_{2}$ (in demineralised water) and stirred for five minutes. The solution was left overnight undisturbed. Next day it was filtered through Whatman 42 filter paper, $500 \mathrm{ml}$ of this filtered water required $6.0 \mathrm{ml}$ of $5 \% \mathrm{NaHSO}_{4}$ (in demineralised water) for neutralization to 
SOUTHERN BRAZILIAN JOURNAL OF CHEMISTRY

SOUTH. BRAZ. J. CHEM., Vol. 21, No. 21, 2013

84

Deflusoridating Filter

Table 1 Analysis and Treatment of Water Sample of Village Shola (Pilaniyon Ki Dhani).

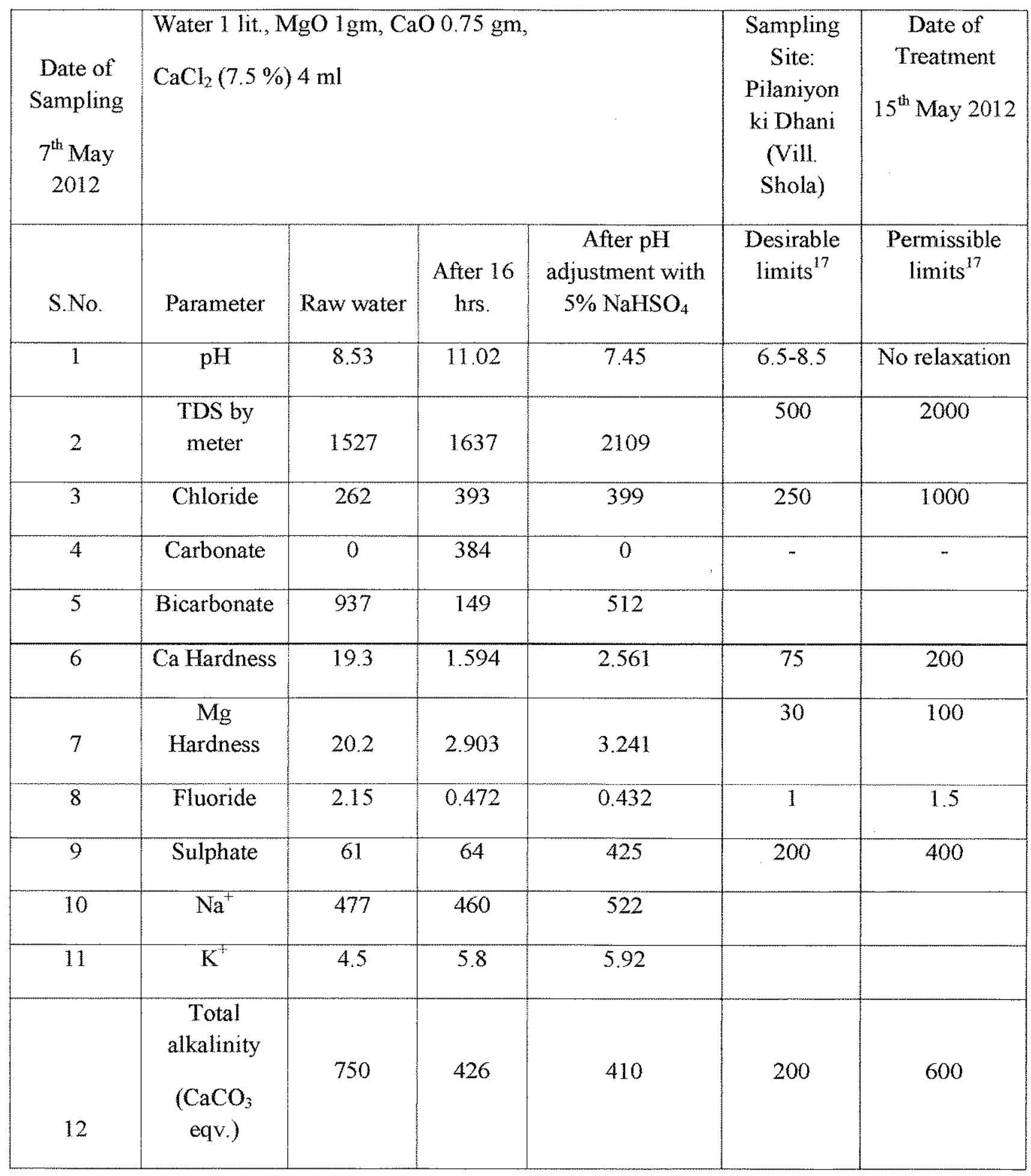




\section{SOUTHERN BRAZILIAN JOURNAL OF CHEMISTRY \\ SOUTH. BRAZ. J. CHEM., Vol. 21, No. 21, 2013}

K.Margandan, R.Agrawal, K.Singh, R.Acharya, S. Sharma and K. Qanungo

pH 7.45 (Table 1). We found that the fluoride concentration reduced from 2.15 in raw water to $0.47 \mathrm{ppm}$ in $\mathrm{pH}$ adjusted water (Table 1). To our expectation, we found that Total Alkalinity had decreased from 750 to $426 \mathrm{ppm}$ (Table 1), as $\left(\mathrm{HCO}_{3}{ }^{-1}\right.$ had precipitated as $\left.\mathrm{CaCO}_{3}\right)$.

However, it was observed that $\mathrm{SO}_{4}{ }^{2 *}$ concentration increased considerably from $61 \mathrm{ppm}$ in raw water to $425 \mathrm{ppm}$ in $\mathrm{pH}$ adjusted water (Table 1), beyond the permissible limit of $400 \mathrm{ppm}^{17}$. Therefore the $\mathrm{pH}$ adjustment with $\mathrm{NaHSO}_{4}$ was not suitable. $\mathrm{pH}$ adjustment with $\mathrm{H}_{2} \mathrm{SO}_{4}$ was ruled out for the same reason (it would have increased the sulphate concentration).

Since nitrate concentration in raw water was found to be $161 \mathrm{ppm}$, one and half times the permissible limit of $100 \mathrm{ppm}^{17}$, pH adjustment with nitric acid would not be suitable. Therefore dilute $\mathrm{HCl}$ was tried for $\mathrm{pH}$ adjustment.

$$
\mathrm{CO}_{3}^{2-}+\mathrm{HCl} \rightarrow \mathrm{HCO}_{3}^{-}+\mathrm{Cl}^{-}
$$

Next, 1.0 liter raw water sample was treated with, $1.0 \mathrm{gm} \mathrm{MgO}, 0.75 \mathrm{gm} \mathrm{CaO}, 4.0 \mathrm{ml}$ $\mathrm{CaCl}_{2}$ (in demineralised water) and left overnight. Next day this water was filtered and, $400 \mathrm{ml}$ of the filtrate was titrated $\mathrm{pH}$ metrically to determine the volume of $0.38 \mathrm{~N} \mathrm{HCl}$ required for neutralization. The variation of $\mathrm{pH}$ with volume of $0.38 \mathrm{~N} \mathrm{HCl}$ added is shown in Fig. 2. Notice that the $\mathrm{CO}_{3}{ }^{2-} \leftrightarrow \mathrm{HCO}_{3} \leftrightarrow \mathrm{H}_{2} \mathrm{CO}_{3}$ equilibrium is apparent. We found 5.6 to $9.6 \mathrm{ml}$ of $0.38 \mathrm{~N} \mathrm{HCl}$ was required to reduce the $\mathrm{pH}$ between 8.5 to 6.5 (within the potable limits) at $927 \mathrm{ppm}^{\mathrm{HCO}_{3}{ }^{-1}}$ conc. in raw water. This translates to 630 to $1008 \mathrm{ml}$ of $0.38 \mathrm{~N} \mathrm{HCl}$ for 45 liters of filtered $\mathrm{MgO}-$ $\mathrm{CaO}-\mathrm{CaCl}_{2}$ treated water.

Dilute $\mathrm{HCl}$ of 0.38 normality was considered to be adequate for $\mathrm{pH}$ adjustment, as it would not be prudent to handle highly concentrated $\mathrm{HCl}$ solution when the filters are put to field trails and possible use in the villages. If too dilute $\mathrm{HCl}$ solution is used the volume of $\mathrm{HCl}$ required would be more. As 1 liter food grade plastic containers are easily available therefore this volume of $\mathrm{HCl}$ solution can be easily dispensed. 
SOUTHERN BRAZILIAN, JOURNAL OF CHEMISTRY

SOUTH. BRAZ. J. CHEM. , Vol. 21, No. 21, 2013

Defluoridating Filker

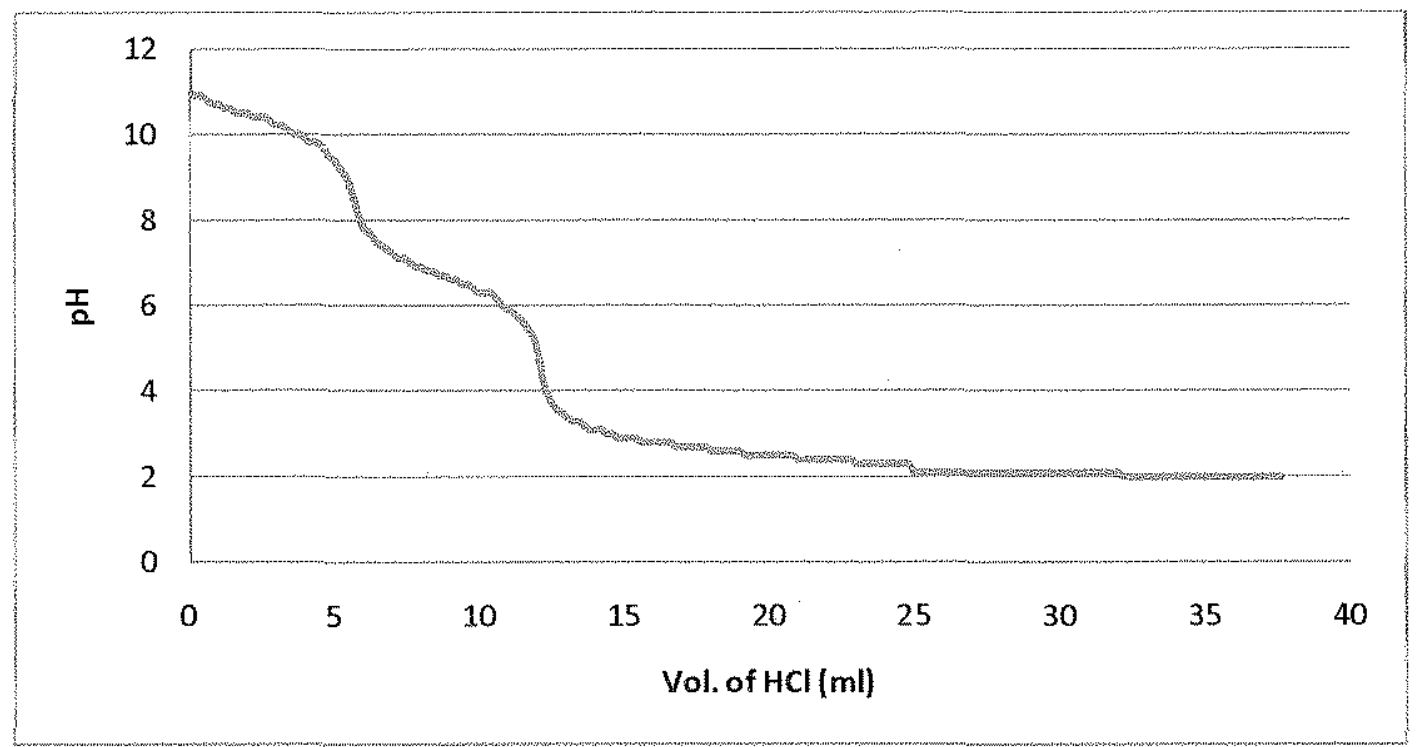

Fig. 2 Variation of $\mathrm{pH}$ of $\mathrm{CaO}-\mathrm{MgO}-\mathrm{CaCl}_{2}$ treated water $(400 \mathrm{ml})$ from Pilaniyon ki Dhani (Village Shola) on addition of $0.38 \mathrm{~N} \mathrm{HCl}$

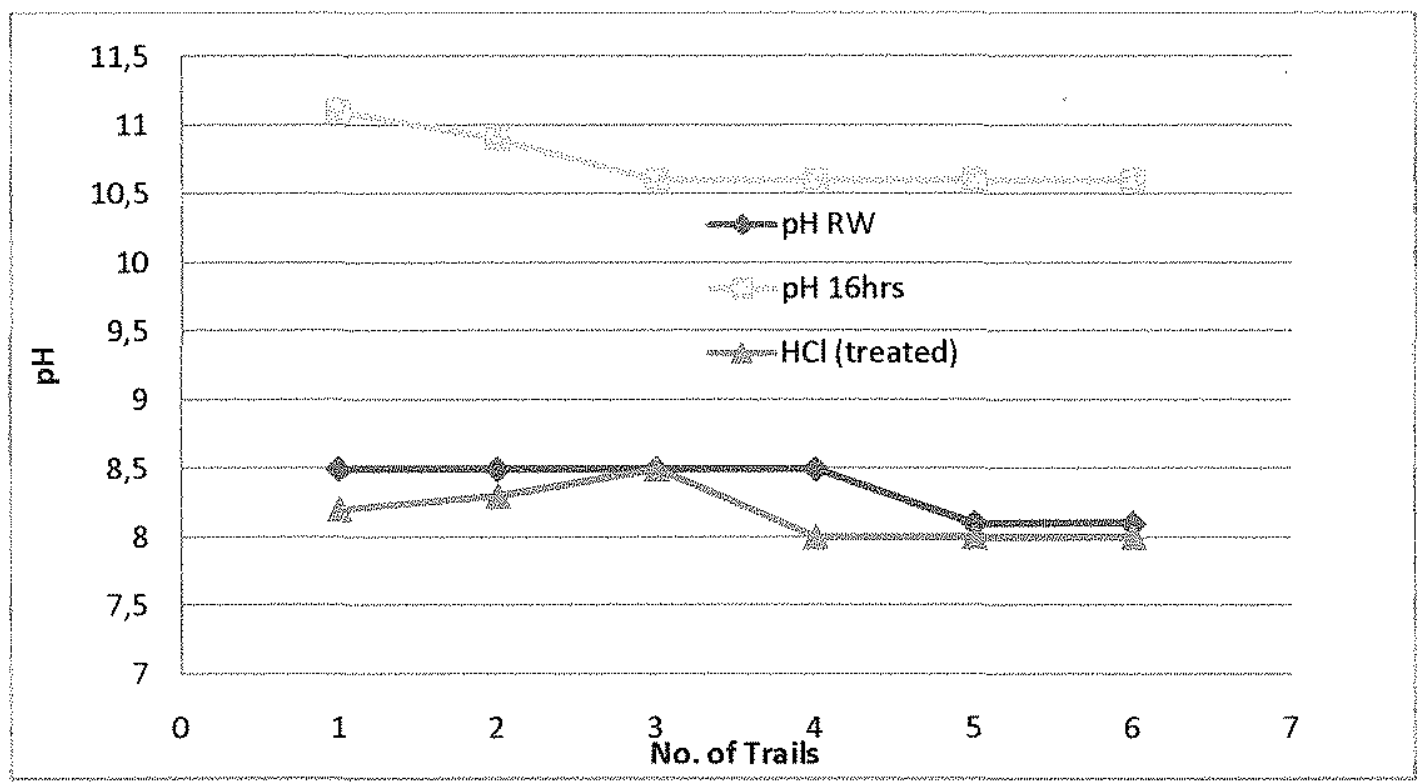

Fig. 3 Variation of $\mathrm{pH}$ during six laboratory trails of the process of $\mathrm{MgO}-\mathrm{CaO}-\mathrm{CaCl}_{2}-\mathrm{HCl}$ treatment with 50 liter raw water from Pilaniyon ki Dhani (Village Shola) 


\section{SOUTHERN BRAZILIAN JOURNAL OF CHEMISTRY \\ SOUTH. BRAZ. J. CHEM., Vol. 21, No.21, 2013}

\section{K.Margandan, R.Agrawal, K.Singh, R.Acharya, S. Sharma and K. Qanungo}

After $\mathrm{pH}$ adjustment by $\mathrm{HCl}$, the $\mathrm{pH}$ of water was 8 to 8.5 , (Fig. 3) with fluoride concentration ranging from 0.7 to $0.86 \mathrm{ppm}$ with an initial fluoride in the raw water varying from 2.26 and $2.3 \mathrm{ppm}$ (Fig. 4). The $\mathrm{CO}_{3}{ }^{-2}$ in $\mathrm{pH}$ adjusted water varied from 30 to $34 \mathrm{ppm}$ when the concentration varied from 30 to $42 \mathrm{ppm}$ (Fig. 5). The bicarbonate concentration in $\mathrm{pH}$ adjusted water was 305 to $420 \mathrm{ppm}$, while it was 934 to $1150 \mathrm{ppm}$ in raw water (Fig. 6). The sulphate concentration was found to be low 40-80ppm (Fig. 7) and chloride concentration 470-581 ppm well within the permisible limit of $1000 \mathrm{ppm}$ (Fig. 8). Also notice, that the method produces water of nearby constant total alkalinity of approximately $400 \mathrm{ppm}$ though the total alkalinity of raw water various from 840 to $1000 \mathrm{ppm}$ (Fig. 9). Thus there is a reduction of total alkalinity by 400ppm. Notice that the TDS of treated water increased by 1200 to $1400 \mathrm{ppm}$ (Fig. 10), in treated water as compared to raw water, but is still very much within the permissible limit of 2000 ppm $^{17}$

As the solubility $\mathrm{Mg}(\mathrm{OH})_{2}$ in water is low $\left(5.0 \times 10^{-12}\right)^{18}$, therefore $\mathrm{Mg}^{2+}$ concentration in raw water and treated water does not vary appreciably (average concentration 38 ppm) (Fig. 11). The Calcium added in form of $\mathrm{CaO}$ and $\mathrm{CaCl}_{2}$, gets precipitated in form of $\mathrm{CaCO}_{3}$, and the concentration of $\mathrm{Ca}^{2+}$ decrease from $15 \mathrm{ppm}$ in raw water to 4 to $5 \mathrm{ppm}$ in $\mathrm{pH}$ adjusted water (Fig. 12). For the above reasons the Total Hardness was also found to decrease (Fig. 13).

There is no significant change in $\mathrm{Na}^{+}$and $\mathrm{K}^{+}$values in raw and treated water which average $300-500 \mathrm{ppm}$ in the various samples. It was found using six layers of cloth for filtering and one tap as outlet it took on an average $2.5 \mathrm{hrs}$ for 45 liter of $\mathrm{MgO}-\mathrm{CaO}-\mathrm{CaCl}_{2}$ treated water to filter through and the filter cloth had to removed and cleaned twice to remove the fine particles of sludge. Hence two taps were fitted 6 inches apart, after which it took only 45 minutes for filtration. It was observed the filter cloth did not choke in the new arrangement. Notice that the volume of filtered water is 45 liter in the second container which increased to 45.6 liters on addition of $600 \mathrm{ml} 0.38 \mathrm{~N} \mathrm{HCl}$. 
SOUTH. BRAZ. J. CHEM., Vol. 21, No.21, 2013

88

\section{Defluoridating Filter}

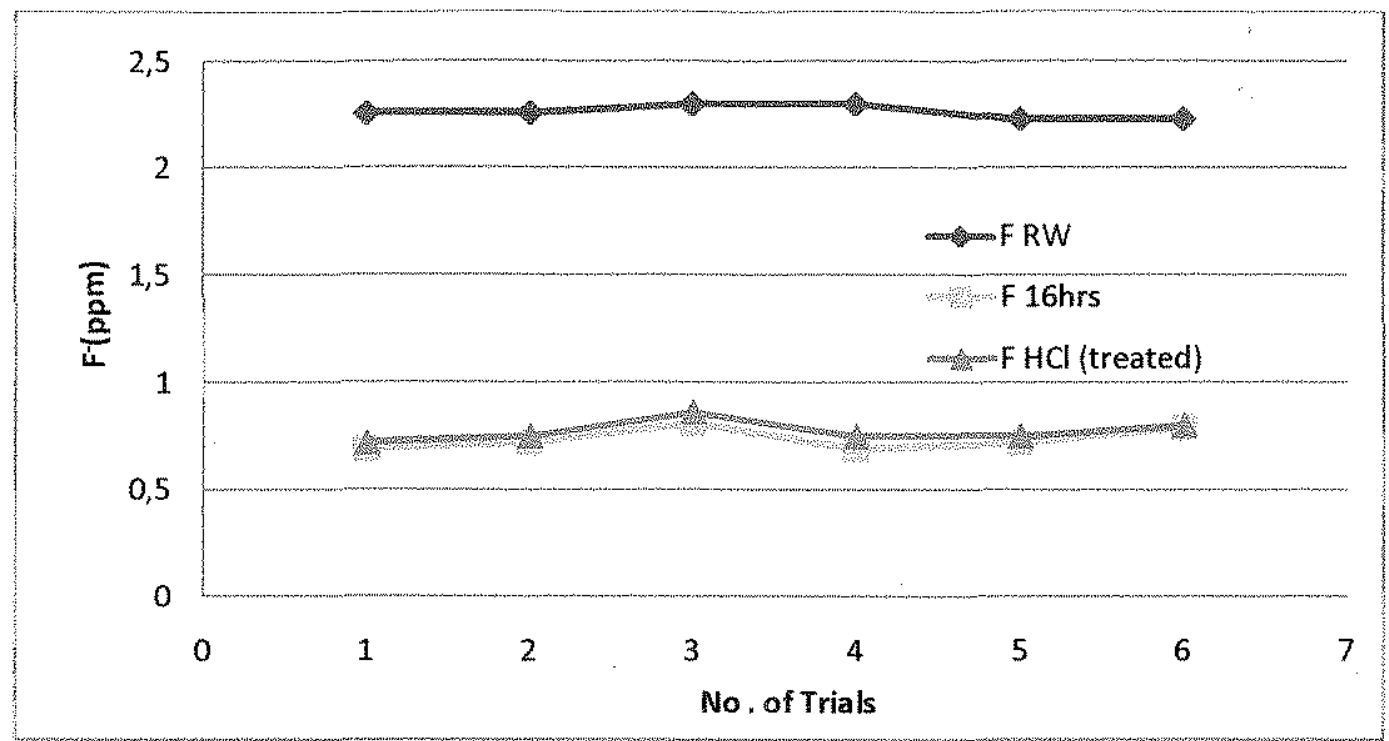

Fig. 4 Variation of $\mathrm{F}^{-}$during six laboratory trails of the process of $\mathrm{MgO}-\mathrm{CaO}-\mathrm{CaCl}_{2}-\mathrm{HCl}$ treatment with 50 liter raw water Pilaniyon ki Dhani (Village Shola)

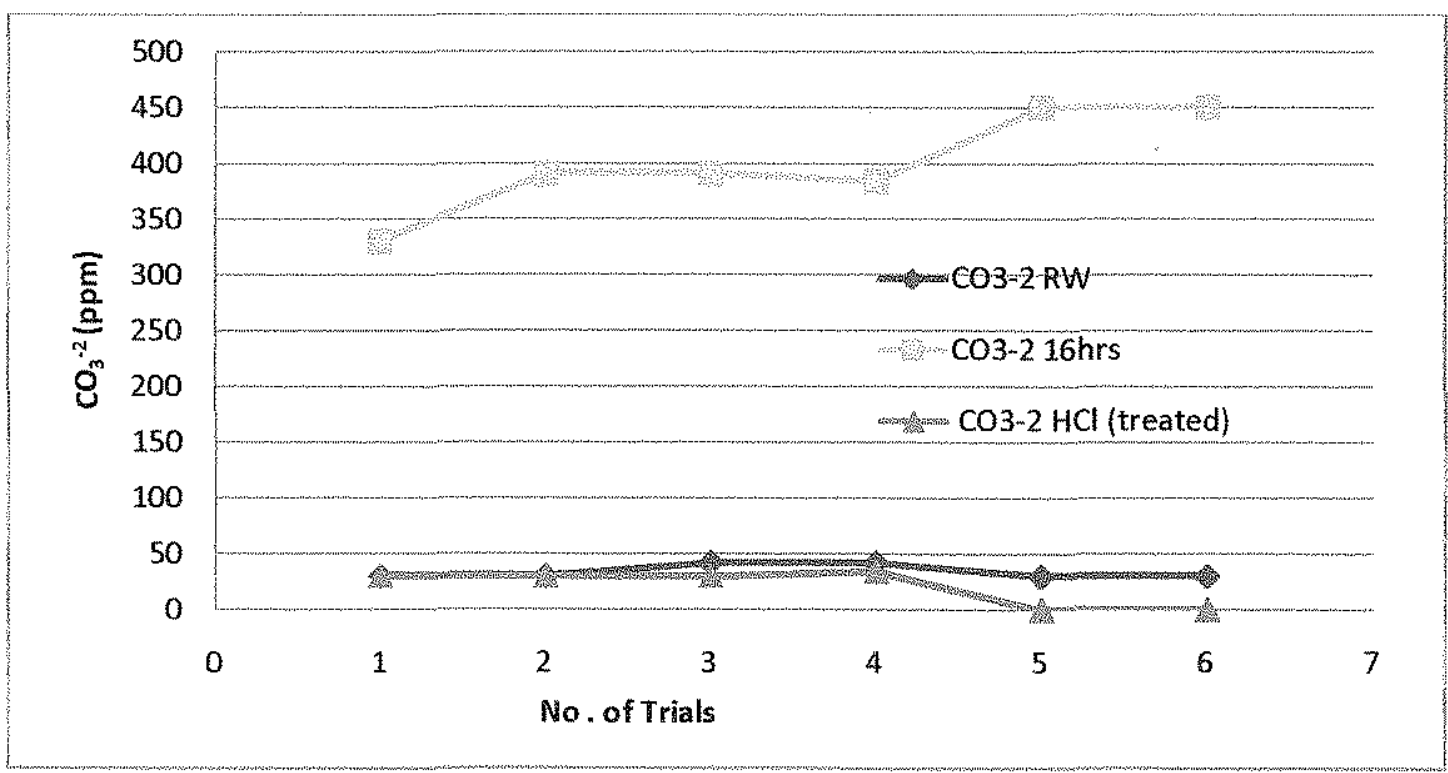

Fig. 5 Variation of $\mathrm{CO}_{3}{ }^{-2}$ during six laboratory trails of the process of $\mathrm{MgO}-\mathrm{CaO}-\mathrm{CaCl}_{2}-\mathrm{HCl}$ treatment with 50 liter raw water from Pilaniyon ki Dhani (Village Shola)

VISIT OUR STE: http:/www.sbjchem.he.com.br 
SOUTH. BRAZ. J. CHEM., Vol. 21, No.21, 2013

K.Margandan, R.Agrawal, K.Singh, R.Acharya, S. Sharma and K. Qanungo

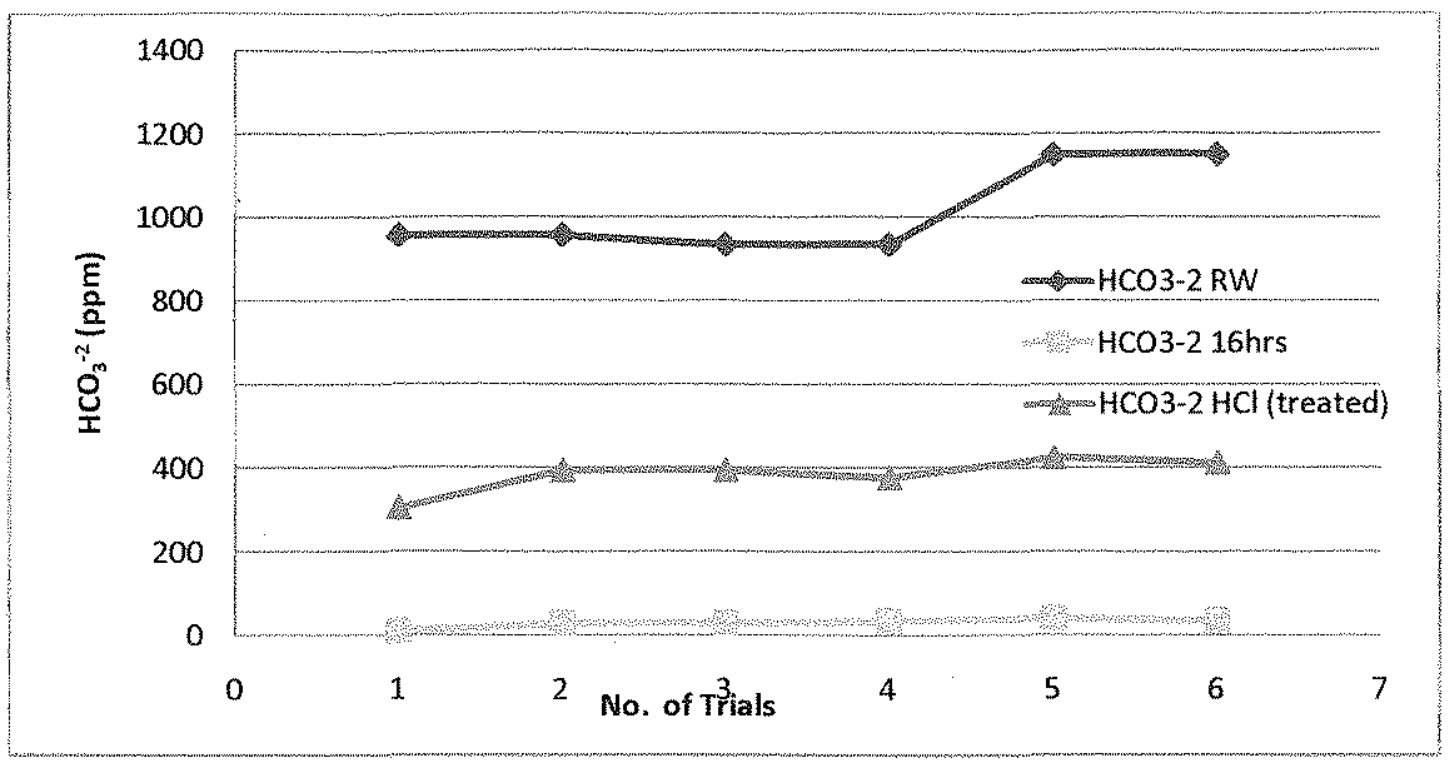

Fig. 6 Variation of $\mathrm{HCO}_{3}{ }^{-1}$ during six laboratory trails of on the process of $\mathrm{MgO}-\mathrm{CaO}-\mathrm{CaCl}_{2}-\mathrm{HCl}$ treatment with 50 liter raw water from Pilaniyon ki Dhani (Village Shola)

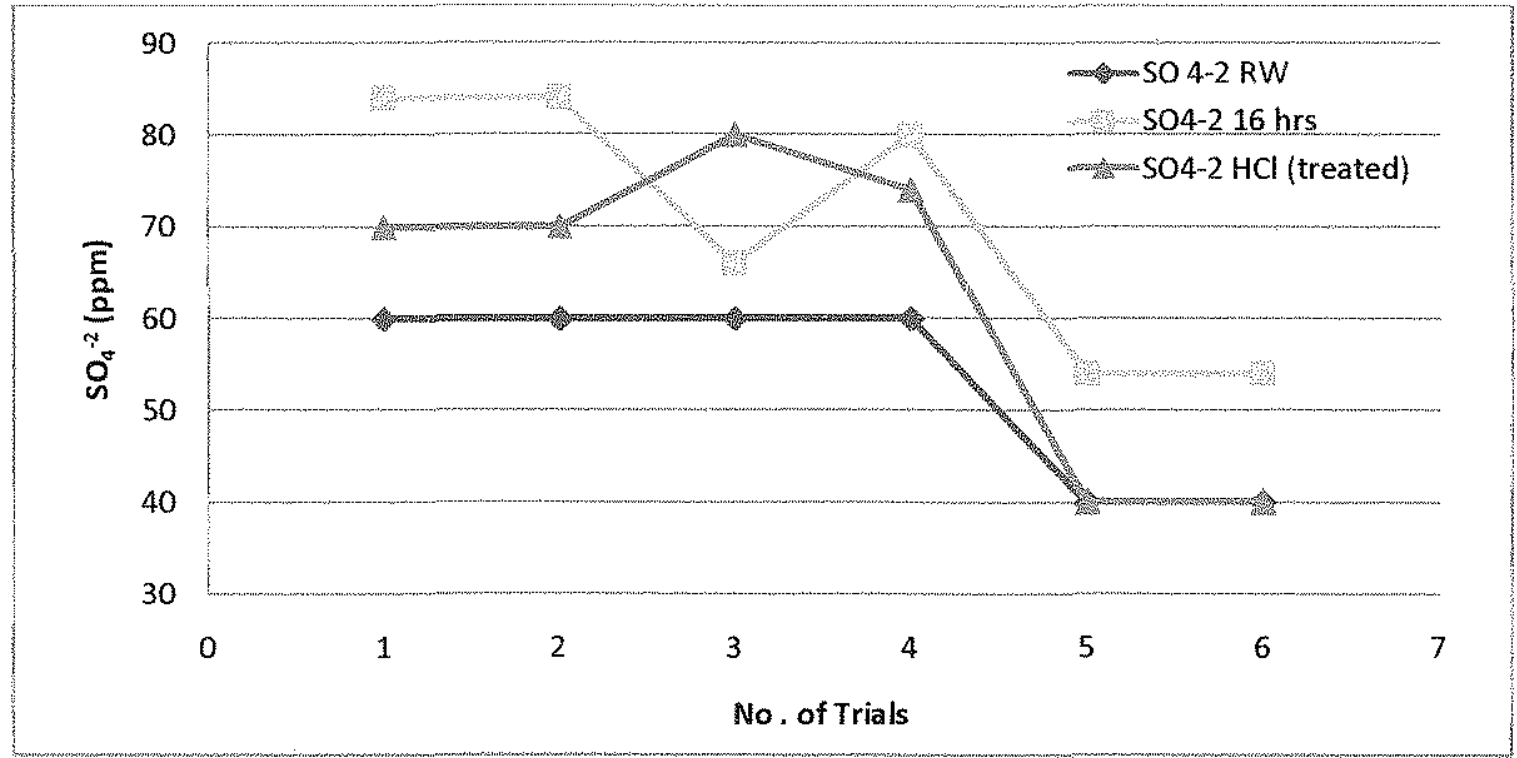

Fig. 7 Variation of $\mathrm{SO}_{4}^{-2}$ during six laboratory trails of on the process of $\mathrm{MgO}-\mathrm{CaO}-\mathrm{CaCl} 2-\mathrm{HCl}$ treatment with 50 liter raw water Pilaniyon ki Dhani (Village Shola) 
SOUTH. BRAZ. J. CHEM., Vol. 21, No.21, 2013

K.Margandan, R.Agrawal, K.Singh, R.Acharya, S. Sharma and K. Qanungo

90

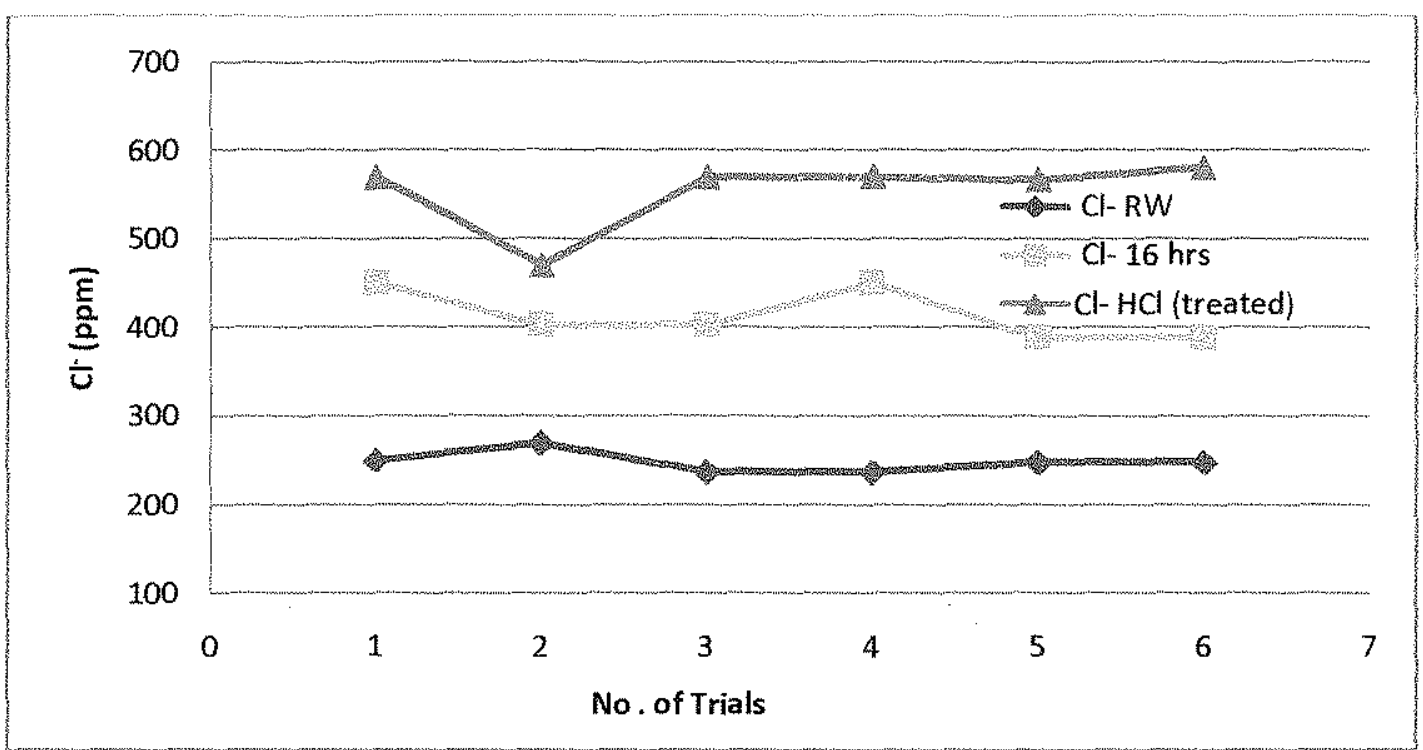

Fig. 8 Variation of $\mathrm{Cl}^{-}$during six laboratory trails of on the process of $\mathrm{MgO}-\mathrm{CaO}-\mathrm{CaCl}_{2}-\mathrm{HCl}$ treatment with 50 liter raw water from Pilaniyon ki Dhani (Village Shola)

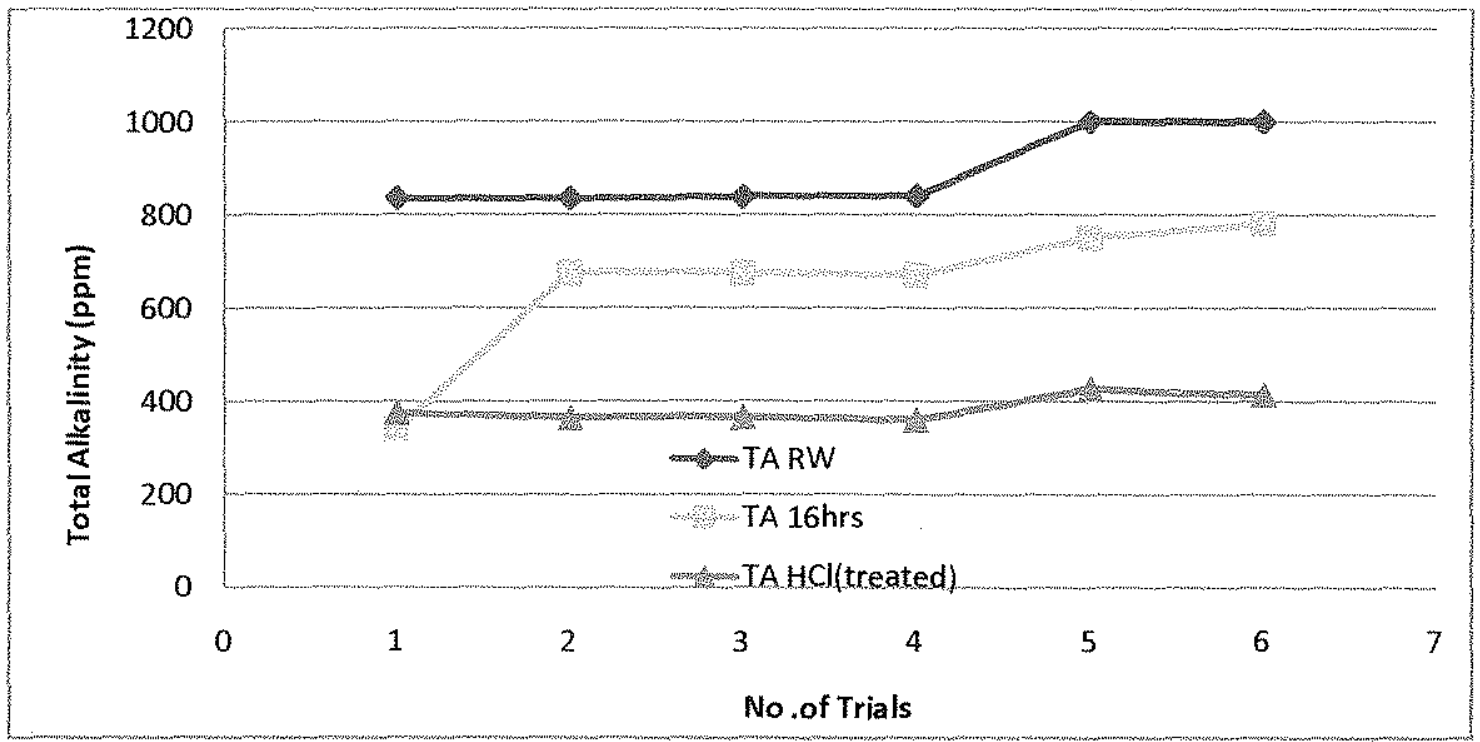

Fig.9 Variation of Total Alkalinity during six laboratory trails of on the process of $\mathrm{MgO}-\mathrm{CaO}$ $\mathrm{CaCl}_{2}-\mathrm{HCl}$ treatment with 50 liter raw water from Pilaniyon ki Dhani (Village Shola) 


\section{SOUTHERN BRAZILIAN, JOURNAL OF CHEMISTRY}

SOUTH. BRAZ. J. CHEM. , Vol. 21, No. 21, 2013

\section{K.Margandan, R.Agrawal, K.Singh, R.Acharya, S. Sharma and K. Qanungo}

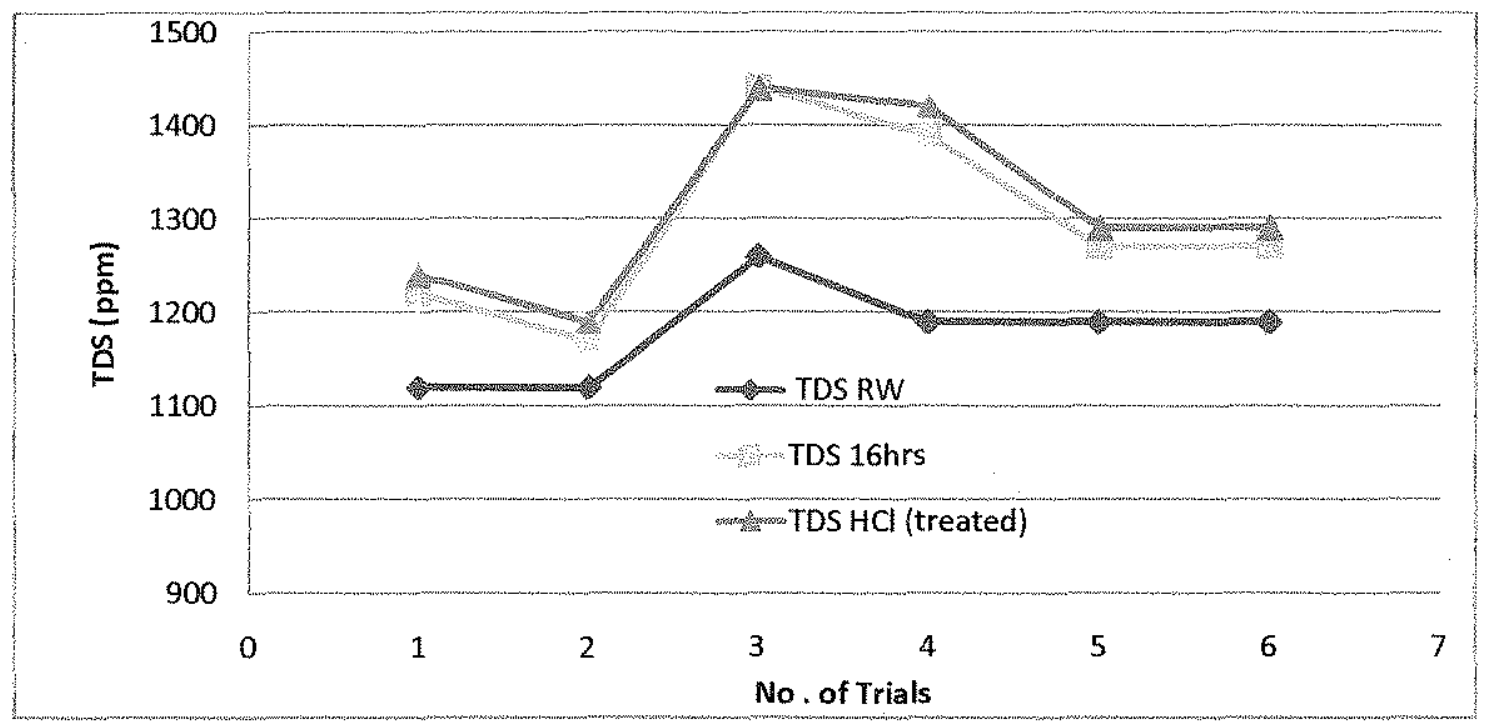

Fig. 10 Variation of TDS during six laboratory trails of on the process of $\mathrm{MgO}-\mathrm{CaO}-\mathrm{CaCl}_{2}-\mathrm{HCl}$ treatment with 50 liter raw water from Pilaniyon ki Dhani (Village Shola)



Fig. 11 Variation of $\mathrm{Mg}^{+2}$ during six laboratory trails of on the process of $\mathrm{MgO}-\mathrm{CaO}-\mathrm{CaCl}_{2}-\mathrm{HCl}$ treatment with 50 liter raw water from Pilaniyon ki Dhani (Village Shola) 
SOUTHERN BRAZILIAN, JOURNAL OF CHEMISTRY SOUTH. BRAZ. J. CHEM. , Vol. 21, No. 21, 2013

92

Defluoridating Filter

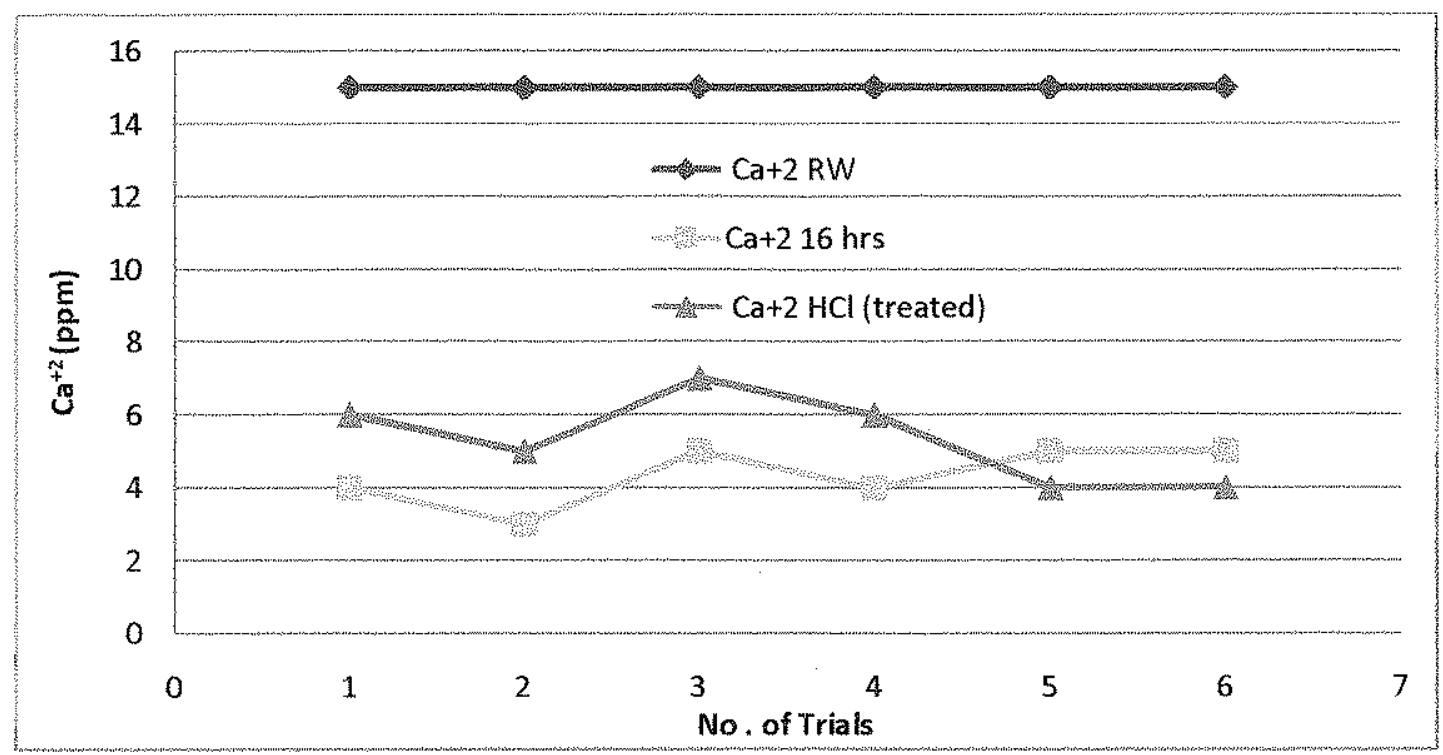

Fig. 12 Variation of $\mathrm{Ca}^{+2}$ during six laboratory trails of on the process of $\mathrm{MgO}-\mathrm{CaO}-\mathrm{CaCl}_{2}-\mathrm{HCl}$ treatment with 50 liter raw water from Pilaniyon ki Dhani (Village Shola)

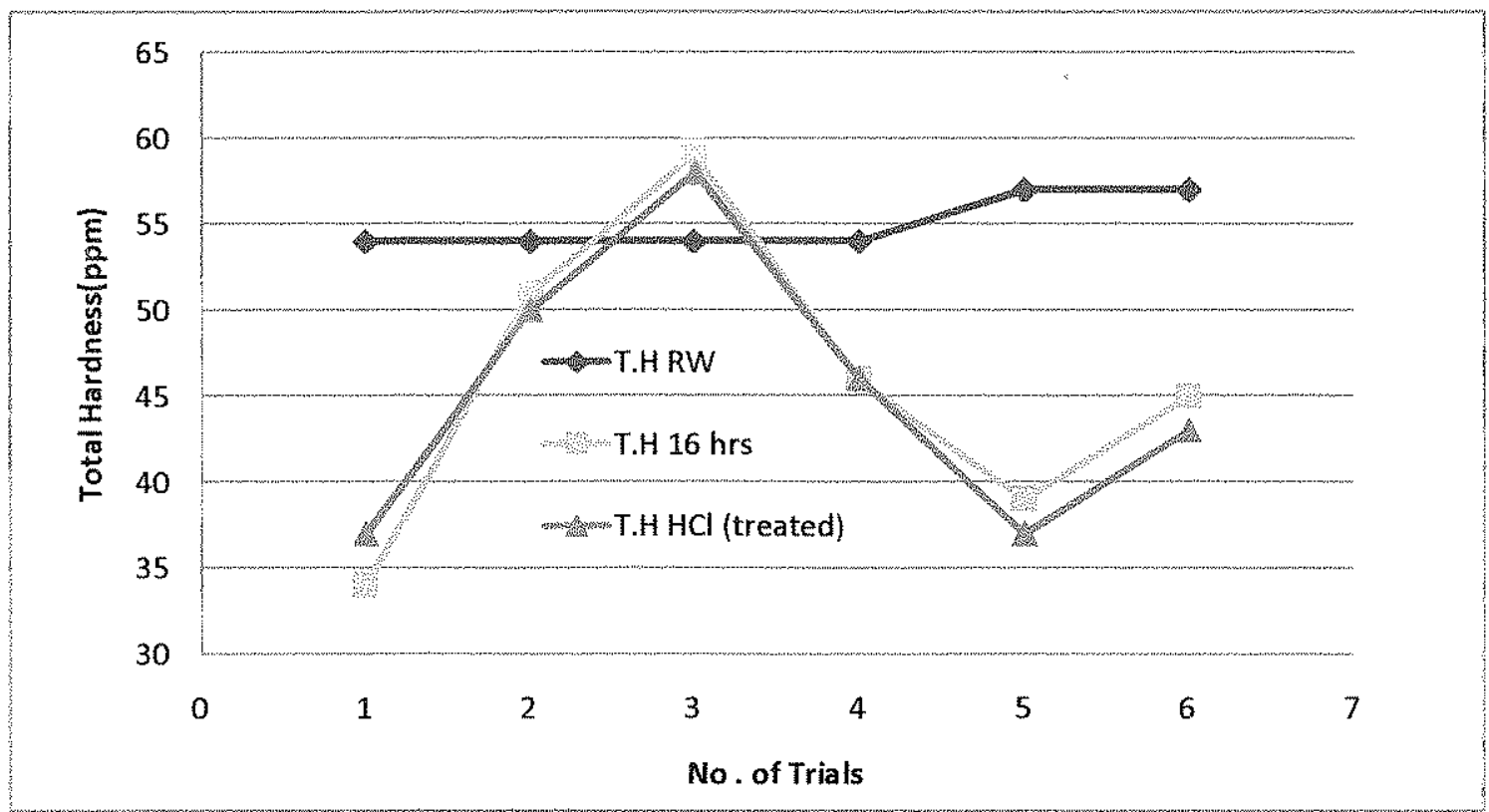

Fig. 13 Yariation of Total Hardness during six laboratory trails of the process of $\mathrm{MgO}-\mathrm{CaO}-$ $\mathrm{CaCl}_{2}-\mathrm{HCl}$ treatment with 50 liter raw water from Pilaniyon ki Dhani (Village Shola) 


\section{SOUTHERN BRAZILIAN JOURNAL OF CHEMISTRY}

SOUTH. BRAZ. J. CHEM., Vol. 21, No. 21, 2013

\section{K.Margandan, R.Agrawal, K.Singh, R.Acharya, S. Sharma and K. Qanungo}

\section{CONCLUSION}

We have determined that the $\mathrm{MgO}-\mathrm{CaO}-\mathrm{CaCl}_{2}$ method of defluoridation can be adopted for water having high alkalinity. Since the local ground water contains high $\mathrm{SO}_{4}{ }^{2-}$ concentration $\mathrm{NaHSO}_{4}$ cannot be added for $\mathrm{pH}$ adjustment, instead $0.38 \mathrm{~N} \mathrm{HCl}$ can be used. The final $\mathrm{Cl}^{-}$ concentration in treated water was found to be within the permissible limits, so were other parameters except nitrate which is very high in the raw water itself.

\section{ACKNOWLEDGEMENTS}

Financial help from DST, Govt. of India is acknowledged in form of project No. (DST/DT/WTI/2k8/95). The authors thank the MITS for providing facilities and support. Prof. S. Sudhakar Rao, IISc, Bangalore is thanked for advice and support.

\section{REFERENCES}

\footnotetext{
${ }^{1}$ Singh, P., Rani, B., Singh, U., Maheshwari, R., 2011, Fluoride Contamination in Groundwater of Rajasthan and its Mitigation Strategies, Journal of Pharmaceutical and Biomedical Sciences, Vol. 6, No. 9, pages 1-12.
}

2 Guidelines for Drinking-Water Quality Incorporating $1^{\text {st }}$ and $2^{\text {nd }}$ Addenda, Vol.1, Recommendations, $3^{\text {rd }}$ Eds., WHO, Geneva, 2008.

${ }^{3}$ For a review see Fawell, J., Bailey, K., Chilton, J., Dahi, E., Fewtrell, L., and Magara, Y., Fluoride in Drinking-Water, WHO-TWA Publishing, London, 2006 and references cited therein.

${ }^{4}$ Susheela, A.K., A Treatise on Fluorosis, $3^{\text {rd }}$ Eds, Fluorosis, Research and Rural Development Foundation, New Delhi, 2007.

${ }^{5}$ Elvove, E., 1940, Removal of Fluoride from Drinking Water. United States Patent No. $2,207,725$. 


\section{SOUTHERN BRAZILIAN, JOURNAL OF CHEMISTRY SOUTH. BRAZ. J. CHEM. , Vol. 21, No. 21, 2013}

\section{Defluoridating Filter}

94

${ }^{6}$ Nagappa, B., Chandrappa, G. T., 2007, Mesoporous Nanocrystalline Magnesium Oxide for Environmental Remediation, Microporous and Mesoporous Materials, Vol. 106, No. 1-3, pages $212-218$.

${ }^{7}$ Zettelmoyer, A.C., Zettlemoyer, E.A., Walker, W.C., 1947, Active Magnesia II Adsorption of Fluoride from Aqueous Solution, Journal of American Society, Vol. 69, No. 6, pages 1312-1315.

${ }^{8}$ Venkateswarlu, P., Narayana Rao, D., 1954, Investigation on the Fluoride Removal from Water, Factors Governing the Adsorption of Fluoride by Magnesium Oxide, Indian Journal of Medical Research, Vol. 42, No. 1, pages 135-140.

${ }^{9}$ Lisle De, A.L., 1967, Means and Methods of Defluoridation of Water. United State Patent No $3,337,453$.

${ }^{10}$ Aravind, V., and Elango, K. P., 2006, Adsorption of Fluoride onto Magnesia-Equilibrium and Thermodynamic Study, Indian Journal of Chemical Technology, Vol. 13, No. 5, pages 476-483.

11 Shihabudheen, M., Maliyekkal, Anshup, K.R., and Pradeep, A, T., 2010, High Yield Combustion Synthesis of Nano Magnesia and its Application for Fluoride Removal, Science of the Total Environment, Vol. 408, No. 10, pages 2273-2282.

${ }^{12}$ Mamatha, P., Rao, S.M., 2011, Defluoridation of Ground Water using Magnesium Oxide, Environmentalist, Vol. 31, No. 1, pages 39-53.

${ }^{13}$ Rao, S.M., Mamatha, P., 2004, Water Quality in Sustainable Water Management, Current Science, Vol. 87, No. 7, pages 942-947.

${ }^{14}$ Rao, S.M., Mamatha, P., Shantha, R.P., Venkatarama Reddy, B.V., 2007, Encapsulation of Fluoride Sludge in Stabilized Mud Block, Water Research Management, Vol. 160, No. 4, pages $167-174$.

${ }^{15}$ Shihabudheen, M., Maliyekkal, Sanjay Shukla, Ligy Philip, Indumathi, M., Nambi, 2008, Enhanced Fluoride Removal from Drinking Water by Magnesia-Amended Activated Alumina Granules, Journal of Chemical Engineering, Vol. 140, No. 1-3, pages 183-192. 


\section{SOUTHERN BRAZILIAN JOURNAL OF CHEMISTRY}

SOUTH. BRAZ. J. CHEM., Vol.21, No.21, 2013

K.Margandan, R.Agrawal, K.Singh, R.Acharya, S. Sharma and K. Qanungo

${ }^{16}$ Application Notes on IISc Method of Defluoridation, http//civilisc.ernet.in/ nsrao/files/applicationliscmethod.pdf

${ }^{17}$ a) Indian Standards for Drinking Water, ISO 10500 http:/hppcb.govin/eiasorang/spec.pdf (date accessed $4^{\text {th }}$ Ocotober, 2012)

b) Indian Standards for Drinking Water, ISO 10500 (1992)

http:/hppcb.gov in/eiasorang/spec.pdf

(date accessed $4^{\text {th }}$ Ocotober, 2012)

${ }^{18}$ Ghoshal, A., Mahapatra, B., Nad, A.K., ${ }^{\text {rd }}$ Eds, An Advanced Course in Practical Chemistry, New Central Book Agency (P) Ltd., Calcutta, 2007

VISTT OUR STTE: http://www.sbjchem.he.com.br 